\title{
Estudo da audição de músicos de rock and roll****
}

\author{
Study of the hearing of rock and roll musicians
}

Juliana Rollo Fernandes Maia*
Ieda Chaves Pacheco Russo**

*Fonoaudióloga. Mestre em Fonoaudiologia pela Pontifícia Universidade Católica de São Paulo. Endereço para correspondência: Av. Manoel da Nóbrega, 412 - Apto. 603 - São Vicente - SP - CEP 11320200 (jurollo@terra.com.br).

**Fonoaudióloga. Professora Titular do Departamento de Clínica Fonoaudiológica e do Programa de Estudos Pós Graduados da Pontifícia Universidade Católica de São Paulo.

***Trabalho Realizado Pontifícia Universidade Católica de São Paulo.

Artigo Original de Pesquisa

Artigo Submetido a Avaliação por Pares

Conflito de Interesse: não

Recebido em 15.08.2006.

Revisado em 28.09.2006; 16.01.2008; 29.01.2008; 8.02.2008

Aceito para Publicação em 8.02.2008.

\begin{abstract}
Background: rock and roll has as one of its main characteristics the excessive sound pressure levels. Several studies have demonstrated that the sound levels of rock concerts can range from 100 to $115 \mathrm{~dB}$ (A), with peak levels of $150 \mathrm{~dB}$ (A). Aim: to study the hearing of rock and roll musicians, analyzing the results of the audiological evaluation and verifying the influence of time of exposure to amplified music. Method: a questionnaire was answered by 23 rock and roll musicians (46 ears) who were also evaluated by means of pure tone audiometry, immitance audiometry and transient/distortion product evoked otoacoustic emissions (OAET and OAEPD). Results: regarding the time of exposure to music, values close to the limit of acceptance (tending to be significants) were found in the frequencies of 0.5 and $6 \mathrm{kHz}$, in the pure tone audiometry. A statistically significant difference was also found in the OAET test in the frequency of $2 \mathrm{kHz}$ and also in the frequencies of $0.75,1,4$ and $6 \mathrm{kHz}$ in the OAEPD test. Conclusion: the results indicate that although hearing loss was not found in the studied population, alteration in the register of the OAE already exists, suggesting alteration of the cochlear function. Regarding time of exposure, the results indicate that musicians with more than 10 years of practice present statistically significant differences when compared to those with less time of exposure.
\end{abstract}

Key Words: Hearing; Hearing tests; Music; Noise effects.

\section{Resumo}

Tema: o rock and roll tem como uma de suas principais características os níveis sonoros elevados. Diversos estudos já constataram que estes níveis variam de 100 a $115 \mathrm{~dB}$ (A), alcançando picos de $150 \mathrm{~dB}$ (A). Objetivo: estudar a audição de músicos de rock and roll, analisando os resultados da avaliação audiológica e investigar a influência da variável tempo de exposição à música amplificada na audição. Método: foi aplicado um questionário em 23 músicos (46 orelhas), e os mesmos foram avaliados por meio da audiometria tonal, audiometria vocal, medidas de imitância acústica e emissões otoacústicas (evocadas por estímulo transiente - EOAT e produto de distorção - EOAPD). Resultados: com relação ao tempo de exposição à música, foram encontrados valores próximos do limite de aceitação (tendendo a ser significantes), nas freqüências de 0,5 e $6 \mathrm{kHz}$, na audiometria tonal. Também foi encontrada diferença estatisticamente significante na freqüência de $2 \mathrm{kHz}$, no teste de EOAT e diferença estatisticamente significante nas frequiências de 0,75, 1,4 e 6kHz, no teste de EOAPD. Conclusões: os resultados mostraram que apesar de não ocorrer perda auditiva na população estudada, já existe alteração no registro das EOA, o que sugere alteração da função coclear. Com relação ao tempo de exposição, os resultados demonstraram que os músicos com carreira superior a dez anos apresentaram diferença estatisticamente significante comparados aos que estão expostos a menos tempo.

Palavras-Chave: Audição; Testes auditivos; Música; Efeitos do ruído. 


\section{Introduction}

The Rock and roll has as one of its characteristics the high sound levels. Diverse studies had evidenced that the levels found in Rock concerts vary from 100 to $115 \mathrm{~dB}(\mathrm{~A})$, reaching peaks of up to $150 \mathrm{~dB}(\mathrm{~A})(1-3)$.

Rock musicians are exposed in their daily activities to high pressure sound levels, however with the aggravating that, in the majority of the times, they do not use protection equipment and they are unaware of the auditory damages that can elapse from this exposition.

In Brazil, few studies had been carried through with musicians with regards to the complaints related to hearing, as well as the audiological profile of these professionals $(1,4-5)$.

The risk of hearing loss does not only exist after long exposition to amplified music. Short expositions to the excessively high sound levels, as in Rock concerts, can also cause hearing loss and tinnitus (6-7).

Ahead of these considerations we question: How would the hearing status of the of Rock musicians who are exposed to electronically amplified music, in the majority of the times without adequate protection, in levels above of $85 \mathrm{~dB}$ (A) be?

\section{Objectives}

1. To raise the auditory and extra-auditory complaints of this population.

2. To analyze the results of hearing evaluation threshold audiometry, measures of acoustics immittance and otoacoustic emissions evoked by transient stimulation (EOAT) and otoacoustic emissions - product of distortion (EOAPD).

3. To investigate the influence of the variable exposure time to amplified music in the hearing of the musicians.

\section{Method}

A descriptive transversal study was carried through in the period from October of 2005 to February of 2006. Obeying to ethical principles, all the participants had received an information letter and had signed a free and clarified consent form.

This study was approved by the Committee of Ethics in Research of the Pontifical Catholic University of São Paulo under protocol number 0010/2005.

Eighty (80) musicians were selected for the research and no musician denied participating, also demonstrating great interest for the research. However, as the musicians were convoked, the difficulties appeared, since a great number scheduled the appointments and did not shown up. Another difficulty was the schedule availability caused by the commitments of assays and presentations.

The variables established that could intervene with the study were established, in order to hinder the commitment or risk to invalidate the research, defining the following selection criteria:

1. The participants could not present historical of otological alteration (otitis of repetition and/or surgeries), neither familial antecedent of hearing impairment.

2. The participants could not have presented exposition to industrial noise.

Twenty-three (23) musicians were evaluated (46 ears), being 19 (83\%) males and 4 (17\%) females, with ages ranging from 21 to 38 years. The highest percentage $(57 \%)$ was in the range between 21 and 26 years. With regards to time in the profession, it varied from 2 to 20 years, being that $65 \%$ were between 2 and 10 years in this type of profession. The amount of time of weekly exposition to music varied from 6 to 63 hours, being that $44 \%$ were exposed to music from 6 to 15 weekly hours.

All the procedures were carried through with the musicians in an acoustic rest of 14 hours. Previously to the hearing evaluation, a meatoscopy was carried through in order to verify whether some obstruction for the accomplishment of the tests existed.

A questionnaire with the aim of raising personal data, health, exposition to amplified music, complaints and variables that could influence the obtained results were applied.

The audiometric test was carried through in an acoustics cabin and audiometer AC33 (Interacoustics) was used calibrated accordingly to norm ISO 8253-1 (1989), with phones TDH 39 (cushion MX - 41/AR).

The acoustics immittance measures were composed by tympanometry and search of the contralateral acoustic reflex in the frequencies of $0.5,1,2$ and $4 \mathrm{kHz}$, according to criteria proposed by Russian et al. (8). Immittance meter of the Interacoustics brand model AZ 7was used, with the probe of $223 \mathrm{~Hz}$ and phones TDH 39 (cushion MX - 41/AR).

The tests of EOAT and EOAPD were carried through in an acoustically treated room with the aim to diminish the influence of ambient noise during the test. In the EOAT test a stimulation of 
the type click was used, which occurs predominantly in the band of the frequencies from of 0.5 to $4 \mathrm{kHz}$ with intensity of $80 \mathrm{~dB}$ NPS. Two hundred and sixty (260) stimulation were used and the bands of register frequencies were 1, 1,5, 2, 3 and $4 \mathrm{kHz}$. For the EOAPD test the intensity relation was of $\mathrm{L} 1=65$ and L2 $=55 \mathrm{~dB}$ NPS, ratio of $\mathrm{f} 2 / \mathrm{f} 1=1,22$ and was applied the protocol "dp-gram" of 0.75 to $8 \mathrm{kHz}$, two points by eighth. The AuDX Plus 50 equipment of Bio-logic System version 32.01.00 was used connected to a Notebook Compaq Presario 1200.

The results of the audiometry were classified in accordance with the type and degree of the hearing loss. The criterion classification used was the average of three frequencies $(0,5,1$ and $2 \mathrm{kHz})$. The presence of audiometric notch was also taken into consideration. The audiometric notch was characterized by a greater or equal difference of 10 $\mathrm{dB} \mathrm{NA}$, in the frequencies of 3 and/or 4 and/or 6 $\mathrm{kHz}$, with relation to previous and/or the posterior one.

In the analysis of the tympano measures only the curves of the type A were considered for being the only ones that indicate a medium ear free of alterations, thus not influencing in the EOA tests. The acoustic reflex was classified as present or absent in each frequency $(0,5,1,2$ and $4 \mathrm{kHz})$.

In the EOAT test we considered present responses that presented reproducibility greater than $50 \%$ and amplitude of the relation signal-noise bigger or equal to $3 \mathrm{~dB}$ NPS in, at least, three bands of tested frequencies.

In the EOAPD test were considered as present responses that presented amplitude of at least $6 \mathrm{~dB}$ NPS above of the first standard deviation of the noise equivalent of the evaluated frequency, or 3 $\mathrm{dB}$ NPS above of the second standard deviation.

All the results were submitted to statistical analysis. The tests of Wilcoxon, Mann-Whitney, T-Student, ANOVAand for comparison of ratio, the Test of Equality of Two Ratios were used. To complement the descriptive analysis, we used the technique of confidence interval for average and ratio. A level of significance of 0,05 was defined (5\%). Initially a comparison between right ear versus left ear was carried through, where we verified that in all the applied tests, significant differences between the ears were not found. This way, the values of each ear were considered for the analysis, doubling the sample size $(\mathrm{N}=46)$.

\section{Results}

The main auditory complaints presented by the musicians were intolerance for intense sounds (48\%), followed by tinnitus $(39 \%)$ and auricular fullness (22\%).

A hundred percent (100\%) of the ears presented thresholds within normal limits. With relation to the audiometric curve, $59 \%$ presented plain curve and $41 \%$, notch in 4-6 kHz. In Table 1 we can observe the median of the audiometric thresholds, as well as the distribution of the results of the preliminary tonal audiometry.

With regards to the tympanometric curve, 46 ears $(100 \%)$ presented type A. With regards to the contralateral acoustic reflex, $100 \%$ were present in the frequencies of 500, 1000 and $2000 \mathrm{~Hz}$. In $4 \mathrm{kHz}$, the presence of contralateral acoustic reflex was found in $65,2 \%$ of the evaluated ears and absence in $34,8 \%$.

The EOAT were present in $39 \%$ of the musicians and absent in $61 \%$. In the EOAPD test the results were: $52 \%$ of presence in the frequency of $750 \mathrm{~Hz}$; $61 \%$ in the frequency of $1000 \mathrm{~Hz} ; 76 \%$ in the frequency of $1500 \mathrm{~Hz} ; 72 \%$ in the frequency of 2000 $\mathrm{Hz} ; 85 \%$ in the frequency of $3000 \mathrm{~Hz} ; 80 \%$ in the frequency of $4000 \mathrm{~Hz} ; 59 \%$ in the frequency of 6000 $\mathrm{Hz}$ and $61 \%$ in the frequency of $8000 \mathrm{~Hz}$.

In Table 2, we observe the results found in the EOAT and EOAPD tests.

In order to analyze the results in relation to the variable career time, we divided the casuistry into two groups: up to 9 years (Group 1 - 30 ears) and 10 years or more (Group 2 - 16 ears) on the basis of median.

Since we obtained statistically significant values only in the results of the amplitude of the relation signal-noise of the EOAPD in groups 1 and 2 with regards to exposition time, these will be presented in Table 3.

TABLE 1 . Median and quartis 1 and 3 of the audiometric thresholds in $\mathrm{dB}$, on the frequencies of 0.25 to $8 \mathrm{kHz}$

\begin{tabular}{lcccccccc}
\hline \hline & $0.25 \mathrm{kHz}$ & $0.5 \mathrm{kHz}$ & $1 \mathrm{kHz}$ & $2 \mathrm{kHz}$ & $3 \mathrm{kHz}$ & $4 \mathrm{kHz}$ & $6 \mathrm{kHz}$ & $8 \mathrm{kHz}$ \\
\hline Mediana & 7,5 & 10 & 5 & 5 & 5 & 5 & 7,5 & 0 \\
Quartil 1 & 5 & 5 & 5 & 0 & 5 & 5 & 5 & 0 \\
Quartil 3 & 10 & 10 & 10 & 10 & 10 & 15 & 13,75 & 5 \\
IC & 1,04 & 1,24 & 1,63 & 1,59 & 1,94 & 2,12 & 2,19 & 1,32 \\
\hline \hline
\end{tabular}


TABLE 2: Average, median, quartis 1 and 3 and shunting line standard of the amplitude of the relation signal-noise of EOAT and EOAPD.

\begin{tabular}{|c|c|c|c|c|c|c|c|c|c|}
\hline & \multicolumn{2}{|c|}{ EOAT } & 1.0 & 1.5 & 2.0 & 3.0 & 4.0 & $1.2-3.4$ & \\
\hline & \multicolumn{2}{|c|}{ Média } & 1,56 & 3,99 & 4,04 & 3,46 & 1,43 & 3,37 & \\
\hline & \multicolumn{2}{|c|}{ Mediana } & 1,4 & 4,3 & 3,6 & 2,3 & 0,6 & 2,2 & \\
\hline & \multicolumn{2}{|c|}{ Desvio Padrão } & 3,26 & 4,42 & 5,01 & 5,52 & 4,37 & 4,23 & \\
\hline & \multicolumn{2}{|c|}{ Quartil 1} & $-0,75$ & 0,80 & 0,58 & 0,30 & $-0,58$ & $-0,08$ & \\
\hline & \multicolumn{2}{|c|}{ Quartil 3} & 3,30 & 6,25 & 7,80 & 6,80 & 2,48 & 5,40 & \\
\hline & \multicolumn{2}{|c|}{ IC } & 0,94 & 1,28 & 1,45 & 1,60 & 1,26 & 1,22 & \\
\hline & & 750 & 1 & 1,5 & 2 & 3 & 4 & 6 & 8 \\
\hline EOA & PD & {$[\mathrm{z}$} & $\mathrm{kHz}$ & $\mathrm{kHz}$ & $\mathrm{kHz}$ & $\mathrm{kHz}$ & $\mathrm{kHz}$ & $\mathrm{kHz}$ & $\mathrm{kHz}$ \\
\hline Média & & 6,16 & 8,10 & 9,55 & 8,69 & 11,64 & 11,06 & 8,17 & 8,88 \\
\hline Mediana & & 6,7 & 9,6 & 10,3 & 8,4 & 10,9 & 11,1 & 8,3 & 9,1 \\
\hline Desvio Padrã & & 5,85 & 5,91 & 6,39 & 6,02 & 6,89 & 8,28 & 9,61 & 7,49 \\
\hline Quartil 1 & & 2,13 & 2,75 & 6,33 & 5,75 & 8,55 & 8,40 & 1,43 & 3,25 \\
\hline Quartil 3 & & 9,53 & 11,85 & 14,20 & 10,60 & 14,85 & 16,20 & 11,93 & 12,20 \\
\hline IC & & 1,69 & 1,71 & 1,85 & 1,74 & 1,99 & 2,39 & 2,78 & 2,17 \\
\hline
\end{tabular}

Table 3: Comparison of the amplitude of the relation signal-noise of the EOAPD in groups 1 and 2 with relation to the exposition time.

\begin{tabular}{|c|c|c|c|c|c|c|c|c|}
\hline & & Média & Mediana & Desvio Padrão & Quartil 1 & Quartil 3 & IC & $\mathrm{p}$-valor \\
\hline \multirow{2}{*}{$750 \mathrm{~Hz}$} & Até 9 & 7,73 & 8,1 & 5,78 & 4,35 & 10,95 & 2,07 & \multirow{2}{*}{$0,011^{*}$} \\
\hline & 10 ou mais & 3,23 & 2,75 & 4,89 & 0,13 & 7,18 & 2,40 & \\
\hline \multirow{2}{*}{$1 \mathrm{kHz}$} & Até 9 & 9,43 & 10,3 & 5,32 & 6,00 & 12,13 & 1,90 & \multirow{2}{*}{$0,036^{*}$} \\
\hline & 10 ou mais & 5,62 & 3,75 & 6,33 & 0,65 & 10,70 & 3,10 & \\
\hline \multirow{2}{*}{$1,5 \mathrm{kHz}$} & Até 9 & 10,39 & 10,8 & 5,91 & 8,13 & 14,53 & 2,11 & \multirow{2}{*}{0,222} \\
\hline & 10 ou mais & 7,96 & 8,6 & 7,15 & 3,38 & 12,85 & 3,50 & \\
\hline \multirow{2}{*}{$2 \mathrm{kHz}$} & Até 9 & 9,36 & 8,8 & 5,73 & 6,10 & 11,88 & 2,05 & \multirow{2}{*}{0,304} \\
\hline & 10 ou mais & 7,43 & 7,85 & 6,52 & 1,60 & 9,45 & 3,20 & \\
\hline \multirow{2}{*}{$3 \mathrm{kHz}$} & Até 9 & 12,82 & 12,8 & 6,96 & 8,73 & 14,85 & 2,49 & \multirow{2}{*}{0,113} \\
\hline & 10 ou mais & 9,43 & 9,55 & 6,38 & 6,63 & 13,30 & 3,13 & \\
\hline \multirow{2}{*}{$4 \mathrm{kHz}$} & Até 9 & 13,38 & 12,9 & 7,45 & 8,75 & 17,95 & 2,66 & \multirow{2}{*}{$0,008^{*}$} \\
\hline & 10 ou mais & 6,72 & 9,2 & 8,21 & 4,58 & 11,18 & 4,02 & \\
\hline \multirow{2}{*}{$6 \mathrm{kHz}$} & Até 9 & 10,50 & 10,8 & 9,99 & 4,63 & 12,95 & 3,57 & \multirow{2}{*}{$0,023^{*}$} \\
\hline & 10 ou mais & 3,81 & 3,5 & 7,29 & 1,00 & 8,13 & 3,57 & \\
\hline \multirow{2}{*}{$8 \mathrm{kHz}$} & Até 9 & 9,71 & 9,5 & 7,63 & 4,60 & 12,83 & 2,73 & \multirow{2}{*}{0,305} \\
\hline & 10 ou mais & 7,31 & 6,65 & 7,20 & 1,25 & 10,93 & 3,53 & \\
\hline
\end{tabular}

*valores considerados estatisticamente significantes perante o nível de significância adotado. 


\section{Discussion}

We could observe that the intolerance to intense sounds was the complaint that predominated. These data agree to the ones described on the literature, which point tinnitus and intolerance to intense sounds as frequent complaints of the musicians $(6,9,10-16)$.

Although $100 \%$ of the ears presented auditory thresholds within normal limits, the distribution of the tonal thresholds showed a great concentration of worse thresholds in the frequencies of 3, 4 and 6 $\mathrm{kHz}$, exactly the first frequencies to be affected in the process of noise induced hearing loss (PAINEPS).

These data corroborate to other studies, in which alterations of the auditory thresholds were not found (17-18). On the other hand, our data disagree with studies that had found hearing loss in musicians with similar characteristics to the ones of the PAINEPS $(4,12,19)$.

One of the reasons that can explain the preserved auditory thresholds is the age range of the studied population, between 21 and 41 years, with higher concentration between 21 and 26 years (57\%). Moreover, the career time and exposition to music also contributes, since the highest concentration of the studied musicians had been in this profession for less than 10 years $(65 \%)$, with a time of weekly exposure of 6 to 15 hours (44\%). However, the high prevalence of the audiometric notch, can be considered as a signal of alert, since that it can indicate a trend to PAINEPS along the time.

The tympanometric curve of type A was found in $100 \%$ of the ears, fact already expected, ahead of the audiometric results. Thirty four point eight percent $(34.8 \%)$ of the ears presented absence of contralateral acoustic reflex in the frequency of 4 $\mathrm{kHz}$, which confirms the fact that even in normal ears, the absence of the reflex in this frequency does not have diagnostic relevance (20). In the literature, studies carried through with musicians that indicated alteration in the measures of acoustic immittance were not found.

With regards to the ears, $61 \%$ presented absence of responses in the EOAT test. Such prevalence was not expected, since that, even so the subjects are exposed to high levels of sonorous pressure of music, all the musicians presented auditory thresholds up to $20 \mathrm{~dB}$ NA. However, our findings agree to other studies that had already indicated absence of responses in the otoacoustic emissions, even in individuals with normal thresholds $(5,20)$.

The region of frequency of $4 \mathrm{kHz}$ was the one that presented the smallest response amplitude, indicating an initial accomplishment of external cilium cells.

In the EOAPD test, there was response presence in the evaluated frequencies in $50 \%$ of the ears, however with diminished amplitude than when compared to the expected one for the population with normal thresholds. Our results agree to the results in literature $(9,20)$.

We observed that the frequency that presented greater number of absent responses was $0,75 \mathrm{kHz}$, followed by 1,8 and $6 \mathrm{kHz}$. These findings agree to the ones of Fiorini (20), who found absence of responses in high frequencies. The frequency of 6 $\mathrm{kHz}$ was the one that presented the smallest response amplitudes.

The great incidence of absent responses in the low frequencies $(0,75$ and $1 \mathrm{kHz})$ can be explained by the acoustics characteristics of the Rock, that presents a dynamic band of compressed frequencies of sounds, amplification of narrow band and amplified and re-amplified reverberation, also affecting the low frequencies.

With relation to exposure time, there were statistically significant differences in the amplitude of the relation signal-noise of the EOAPD between groups 1 and 2 in the frequencies of $0.75,1,4$ and 6 $\mathrm{kHz}$. Other studies in literature point out the fact that the greater the exposure time to music, greater auditory damage can be found $(15,19)$.

In general, in the present study the time of exposition to music influenced in the obtained results. We can infer that there is already an initial accomplishment of the external cilium cells. However, as in any test, the responses must be analyzed in set with other results, as well as a longitudinal accompaniment of each case must be carried through. Another important point to stand out is the reduced number of the studied population.

In order that generalizations and standards of the analysis of the results can be made, other studies must be carried through, expecting to evaluate a bigger number of musicians.

Moreover, measures that can be taken aiming to diminish the risks that Rock musicians are exposed do exist. Currently, auditory protection for this population already exists, with specific filters of frequencies and characteristics that best attend to the type of music executed (21-22).

Moreover, the awareness by the part of the 
musicians concerning the danger of extreme intensities of music is also necessary. Only when musicians present conscience of signals and decurrent symptoms of the exposition to high levels of sound pressure, the auditory preservation can be implanted with higher efficiency.

\section{Conclusão}

The main auditory complaints found were intolerance for intense sounds (48\%), tinnitus (39\%) and irritability and nervousness (35\%).

$.100 \%$ of the ears presented auditory thresholds within normal limits;

$.41 \%$ of the ears presented audiometric notch in 4$6 \mathrm{kHz}$

$.100 \%$ of the ears presented tympano measures of type A bilaterally and the presence of contralateral acoustic reflex bilaterally in the frequencies of 0.5 , 1 and $2 \mathrm{kHz}$. In $4 \mathrm{kHz}$, the presence of contralateral acoustic reflex was found in $65,2 \%$ of the evaluated

\section{References}

1. Mordini CA, Branco FCA, Rodrigues PF. Um estudo sobre os efeitos da exposição à música em músicos de rock and roll [monografia]. São Paulo: Pontifica Universidade Católica de São Paulo; 1994.

2. Sallows K. Listen while you work: hearing conservation for the arts. Vancouver: Shape - Safety and health in arts production and entertainment; 2001.

3. Chasin M. Music and hearing aids. The Hearing Journal. 2003;56(7):36-41.

4. Samelli AG, Schochat E. Perda auditiva induzida por nível de pressão sonora elevado em um grupo de músicos profissionais de rock-and-roll. Acta Awho. 2000;19(3):13643.

5. Andrijauskas S. Estudo dos achados das emissões otoacústicas evocadas por transiente em músicos de rock and roll [dissertação]. São Paulo: Pontifícia Universidade Católica de São Paulo; 2001.

6. Almstedt AC, Gustafsson T, Axelsson A. Risk of hearing damage in connection with pop and rock concerts. The maximum permissible sound level should be legally confirmed. Lakartidningen. 2000;97(10):1102-4.

7. Cassano F, Bavaro P, De Marinis G, Aloise I. Nooccupational exposure to noise. G Ital Med Lav Ergon. 2005;27(2):157-9.

8. Russo ICP, Santos TMM. A prática da audiologia clínica. $5^{a}$ ed. rev. aum. São Paulo: Cortez; 2005. ears and absence in $34,8 \%$;

. in the EOAT test, $39 \%$ of responses were present and $61 \%$ were absents;

. in the EOAPD test, there was response presence in the evaluated frequencies in more than $50 \%$ of the ears;

. with regards to the exposure time to music, values had been found close to acceptance limit (tending to be significant), in the frequencies of 0.5 and 6 $\mathrm{kHz}$, in the tonal audiometry. Statistically significant difference was found in the frequency of $2 \mathrm{kHz}$, in the EOAT test and in the frequencies of $0.75,1,4$ and $6 \mathrm{kHz}$, in the EOAPD test;

. although hearing loss does not occur in the studied population, alteration in the register of the EOA exists, what suggests alteration in the cochlear function;

. with regards to the exposure time, musicians with career time superior to 10 years presented worse results when compared to the musicians with smaller exposure time.
9. Silveira JAM, Brandão ALA, Rossi JD, Ferreira LLA, Name MAM, Estefan P, et al. Avaliação da alteração auditiva provocada pelo uso do walkman, por meio da audiometria tonal e das emissões otoacústicas (produtos de distorção): estudo de 40 orelhas. Rev Bras Otorrinolaringol. 2001;65(5):650-4.

10. Marchiori LLM, Melo JJ. Comparação das queixas auditivas com relação à exposição ao ruído em componentes de orquestra sinfônica. Pró-fono Rev. Atual. Cient. 2001;13(1):9-12.

11. Walter O, Wienke A. Hearing defects after a rock concert. Laryngorhinootologie. 2002;81(10):739-40.

12. Kaharit K, Zachau G, Eklof M, Sandsjo L, Moller C. Assessment of hearing and hearing disorders in rock/jazz musicians. Int J Audiol. 2003;42(5):279-88.

13. Laitinen HM, Toppila EM, Olkinuora PS, Kuisma K. Sound exposure among the finnish national opera personnel. Appl Occup Environ Hyg. 2003;18(3):177-82.

14. Bray A, Szymanski M, Mills R. Noise induced hearing loss in dance music disc jockeys and an examination of sound levels in nightclubs. J Laryngol Otol. 2004;118(2):123-8.

15. Hagberg M, Thiringer G, Brandstrom L. Incidence of tinnitus, impaired hearing and musculoskeletal disorders among students enrolled in academic music education - a retrospective cohort study. Int Arch Occup Environ Health. $2005 ; 78(7): 575-83$. 
16. Schmuziger N, Patscheke J, Probst R. Hearing in nonprofessional pop/rock musicians. Ear Hear. 2006;27(4):321-30.

17. Axelsson A, Eliasson A, Israelsson B. Hearing in pop/ rock musicians: a follow-up study. Ear Hear. 1995;16(3):24553

18. Kahari KR, Axelsson A, Hellstrom PA, Zachau G. Hearing assessment of classical orchestral musicians. Scand Audiol. 2001;30(1):13-23.

19. Juman S, Karmody CS, Simeon D. Hearing loss in steelband musicians. Otolaryngol Head Neck Surg. 2004;131(4):461-5.
20. Fiorini AC. O uso de registros de emissões otoacústicas como instrumento de vigilância epidemiológica de alterações auditivas em trabalhadores expostos a ruído [tese]. São Paulo: Faculdade de Saúde Pública da Universidade de São Paulo; 2000 .

21. Laitinen H. Factors affecting the use of hearing protectors among classical music players. Noise Health. 2005;7(26):21-9.

22. Bogoch II, House RA, Kudla I. Perceptions about hearing protection and noise-induced hearing loss of attendees of rock concerts. Can J Public Health. 2005;96(1):69-72. 